\title{
THE TRUE AND FAIR VIEW CONCEPT IN ROMANIA: A CASE STUDY OF CONCEPT TRANSFERABILITY
}

\author{
Cătălin Nicolae Albu \\ Bucharest Academy of Economic Studies, Romania \\ 6 Piața Romană, sector 1, Bucureşti, 010374, Romania
}

Chair of International Accounting and Financial Reporting, room 1117

Tel: +40 7450285 26, Email: catalin.albu@cig.ase.ro

\author{
Nadia Albu \\ Bucharest Academy of Economic Studies, Romania \\ 6 Piața Romană, sector 1, Bucureşti, 010374, Romania \\ Chair of International Accounting and Financial Reporting, room 1117 \\ Tel: +40 7456189 33, Email: nadia.albu@cig.ase.ro \\ David Alexander \\ University of Birmingham \\ Birmingham Business School \\ Edgbaston, Birmingham, B15 2TT, United Kingdom \\ TEL: +44 121414 8027/6530,Email: D.J.A.Alexander@bham.ac.uk
}

$14 / 04 / 09$

\footnotetext{
Version prepared for the $30^{\text {th }}$ Congress of the Association Francophone de Comptabilité, 27 - 29 May 2009, Strasbourg, France
} 


\title{
THE TRUE AND FAIR VIEW CONCEPT IN ROMANIA: A CASE STUDY OF CONCEPT TRANSFERABILITY
}

\author{
"...we shall see that it is easier \\ to knock down a dictator than to push away a dictatorship" (Paler, 1995: 43) \\ «...nous verrons que c'est plus facile d'abattre \\ un dictateur que d'écarter une dictature » (Paler, $1995: 43$ ) \\ „...se va vedea că e mult mai uşor să dobori un dictator \\ decât să înlături o dictatură" (Paler, 1995: 43)
}

\begin{abstract}
There is an enormous literature relating to the true and fair view (hereafter TFV). We are concerned with how the concept is actually perceived by various actors in an emerging economy which has only recently joined the European Union, i.e. Romania. Romania has a code law system with an obvious preference for the legal form. Two main steps have been taken for the purpose of our study. First, textual analysis of all accounting regulations has been performed with respect to the provisions regarding the TFV concept. Second, nine in-depth semi-structured interviews have been conducted with top representatives of the Romanian regulator, preparers, auditors and professional bodies. The perception on TFV depends firstly on the category: for auditors, this is a guide or a vital concept, closely related to substance over form, relevance and usefulness for users, while for regulators and preparers, TFV is primarily compliance with the rules.
\end{abstract}

Keywords: true and fair view, true and fair view override, Romania

\section{Résumé}

Il y a énormément de littérature sur le concept de true and fair view (fr. image fidèle ; ci-après TFV). Nous nous intéressons au mode réel de perception $\mathrm{du}$ concept par différents acteurs dans une économie émergeante qui a très récemment adhéré à la Union Européenne, c'est-a-dire la Roumanie. Le droit roumain est un système de droit écrit, montrant une préférence incontestable pour la forme juridique. Deux approches principales furent explorées : premièrement, une analyse du texte de tous les règlements comptables à-propos du concept de TFV a été menée. Deuxièmement, neuf entretiens en profondeur semi-structurés ont été conduits auprès des représentants du plus haut niveau du régulateur comptable roumain, des personnes chargées de l'établissement des comptes annuels, des auditeurs et des corps professionnels roumains. La perception sur la TFV varie profondément en fonction du type d'acteur : pour les auditeurs, la TFV est un guide ou un concept essentiel, inextricablement lié au principe de substance over form, à la pertinence et à l'utilité pour les utilisateurs, pendant que pour les chargés de l'établissement des comptes et pour le régulateur comptable, TFV désigne essentiellement la conformité aux lois.

Mots clés: true and fair view, dérogation pour image fidèle, Roumanie 


\section{INTRODUCTION}

There is an enormous literature relating to the true and fair view (hereafter TFV). We are not concerned here with details of its origins in the UK (see e.g. Chastney, 1975). We are not even concerned with the precise terminology (true and fair view or fair presentation) (see our note on Saussure in section 2 below). We are not primarily concerned with the problem of translation across European languages (see Alexander, 1993; Nobes, 1993, and a host of more recent papers applying their principles to many individual languages). What we are primarily concerned with is how the concept is actually perceived by various actors in an emerging economy which has only recently joined the European Union (hereafter EU), i.e. Romania. The TFV literature in Romania is very poor and mainly consists of several papers written in a pure descriptive approach, dealing with the meaning of the concept and what its implications are (in general terms), except for Feleagă and Ionaşcu (1998), who critically discuss the nature of TFV at the European level and its stakes in an internationalized world.

The essence of the TFV is that it is undefined. We interpret it as at minimum requiring a presentation which is not misleading. It may be regarded as more-or-less meaningless but nice-sounding words. It may also be regarded as an important high-level objective of financial reporting, which the detailed rules, standards and regulations are designed to achieve and assumed to achieve. It may finally be regarded as the over-riding and ultimately sole purpose of financial reporting, leading to the TFV over-ride which if necessary requires (not allows) departure from detailed rules, standards and regulations (see Walton, 1991; Alexander, 1999, 2001; Nobes, 2000; Evans, 2003 for a deeper discussion of these views). This last over-riding interpretation, explicit in UK law for many decades, is also explicitly required by Article 2 of the Fourth EU Directive. Alexander and Eberhartinger (2009) discuss the implications of the Directive requirement in a national context. The over-ride is also, controversially and in a highly restricted way, required by IAS 1 (using the words 'fair presentation' (para 19)).

To an important extent the debate about the role and (in)significance of TFV can be related to two well-known dichotomies in accounting, principles versus rules (see in particular Alexander and Jermakowwicz (2006) and Benston et al (2006)), and substance over form (hereafter SoF). This latter is in effect a short-hand way of saying that the economic substance of a transaction or event is more important than the legal form. Attitudes to this view are likely to be coloured by two major theoretically distinct but pragmatically related considerations. The first is the legal system in a particular country - a common law system is more likely to be linked with a preference for economic substance and a code law system is more likely to be linked with a preference for legal form. The second is that a reporting system designed for investor needs is more likely to focus on economic substance and a

reporting system designed for tax calculation and prudent dividend distribution is more likely to focus on legal form (see Nobes, 1983, 1998).

International Accounting/Financial Reporting Standards (hereafter IASs) are explicitly focussed on investor needs, as stated in the Framework (IASC, 1989 para 10), which is consistent with the EU requirement to use them for consolidated reports of listed companies. 
Individual company ('legal') reports are not, which suggests that the use of IAS philosophy and requirements in these situations may be both more problematic and less rational. Nevertheless all 27 EU countries have moved their national regulations significantly towards IASs. Romania is no exception.

The history of accounting in Romania through the $20^{\text {th }}$ Century can be briefly summarised as follows. The accounting reforms in Romania generated considerable debate in the national and international literatures (Feleagă, 1992; Delesalle and Delesalle, 2000; Bunea, 2006; Ionaşcu et al., 2007). It is worth noting first that Romania as a country is a fairly recent phenomenon. Moldavia and Wallachia merged in 1859, gaining independence in 1878, thus forming the so-called Kingdom of Romania; later, in 1918 three other Romanian territories (Transylvania, Bukovina and Bessarabia (Eastern Moldavia)) joined the Kingdom of Romania. At the beginning of the Second World War several territories were ceded to various other countries, being only partially recovered after the War. The Kingdom of Romania endured until December 30, 1947 at the abdication of the Romanian King Michael I of Romania, and the establishment of the communist regime. Various component regions were strongly influenced by particular mainland European traditions, including Italian, Germanic and, perhaps especially, French, and Romania followed the chart of accounts tradition through to the 1940s when the communists took control. From 1947 until 1989, Romania had an accounting system of Russian origins where “... accounting was used to offer information for statistical purposes and forecasts at national level" (Calu, 2005: 145). Accounting was not an instrument at the disposal of the management of an enterprise or other entity (e.g. institution, organization), but was required to fulfil the needs of the central institutions of the planned economy (Schroll, 1995).

From its very beginning after the fall of communism, the process of accounting regulation was a public one, deriving from a legislative process where the Ministry of Finance is the main actor (Ionaşcu et al., 2007: 174). The process of accounting reform after the revolution started with the Accounting Law no. 82 of 1991, accompanied by Implementation guidelines (Order of the Minister of Public Finances 704/1993). A middle period between the soviet and the French inspiration regulations is reported afterwards, between 1990 and 1993 (Calu, 2005: 214).

Afterwards, there were three main stages. The first stage was based on French code law accounting; the second stage was an Anglo-Saxon-IFRS-oriented one with the third stage represented by the implementation (enactment) of the European Directives. These changes and the entire evolution were not without their critics (see Roberts, 2000; Bunea, 2006; Ionaşcu et al., 2007), with the main objections aimed at the second phase which was referred to as a "cultural or economical intrusion" by Delesalle and Delesalle (2000) or as "[...] another case of cultural intrusion?" by Roberts (2000).

As previously mentioned, pros and cons of the stages of the accounting reform have been stated. In 2005 the Order of the Minister of Public Finances no. 1752 was issued for the enactment of the $4^{\text {th }}$ and $7^{\text {th }}$ European Directives. Of course shortcomings can be found. For example, OMFP 1752 still allows the use of LIFO as a method of assigning costs to inventories while it is no longer permitted under IAS 2 Inventories. Practitioners have also 
raised some questions about this; for example, they feel the need for supplementary explanations regarding the determination of an active market, the use of fair value or the testing of non-current assets for impairment. As regards consolidated accounts, IFRSs are mandatory for listed companies starting January $1^{\text {st }} 2007$ (Order of the Minister of Public Finances no. 1221/2006), as well as for financial institutions.

It follows from the above historical summary that Romanian accountants are likely to have difficulty with integrating the TFV concept into their previous experience. In this paper we set out to explore the perceptions of representative key players: regulators, preparers, auditors, and professional bodies in relation to TFV by means of in-depth semi-structured interviews. Section 2 below gives an outline of legal/regulatory requirements in Romania since 1989. Section 3, after a note on process and methodology, presents and discusses our finding in depth. Section 4 concludes, arguing that there are significant general messages to be drawn from our particular Romanian case study.

\section{THE TFV IN ROMANIAN REGULATION}

This section explores the development of the TFV concept in Romanian regulations from the fall of communism in 1989 to the membership of the European Union (EU) in 2007. The primary language used is English, but all key terms are presented in three languages: English, French and Romanian. Unlike a number of other ex-communist countries, which took advice from several existing EU members (and therefore received conflicting advice and took the bits they preferred from each source), Romania in the early 1990s only investigated, and adopted/adapted, the French model. This resulted at least in the adoption of a French oriented General Chart of Accounts, although more extensive adoption was not possible. Like those other countries, however, the target at the time was purely preparation for eventual membership of the EU. The focus was therefore the EU Directives, as interpreted by France. Only later in the decade, following direct pressure from the World Bank and general international developments, did IAS thinking gradually become a factor.

The whole paper is written in the context, and needs to be read in the context, of the principles of Saussurean linguistics. In essence this leads to three propositions.

- The use of a particular word as signifier (ro. semnificat; fr. signifié) is arbitrary. There is no rationale for, or significance from, cat being cat and not rumplestiltskin.

- The use of a particularly conceived concept as signified (ro. semnificant; fr. signifiant) is arbitrary. The famous example, from Saussure himself, is that French conceives of two types of river, one that flows directly into the sea and one which does not. Two concepts require two words (un fleuve and une rivière respectively). English thinking never made this conceptual distinction, and therefore only has one word for the one concept: river. Not surprisingly, Romania follows the French conceptualisation, the two words being un fluviu and un râu respectively.

- The relationship between a word and a concept is itself arbitrary. Cat could just as well signify a small nocturnal flying mammal instead of a furry four-legged, one tailed, friendly, independent and potentially vicious mammal, and bat the reverse. 
It follows that the words TFV are context specific in meaning. "True and fair view" in context A may have a different meaning from that in context B. Conversely, "true and fair view" in context A could have an identical meaning to "fair presentation" in context A (or, of course, in context B). Great care is needed by both writer and reader in trying to clarify the complexities which follow from this in a dynamic multi-contextual analysis such as we present here.

The Fourth Directive in English, the Fourth Directive in French, Romanian regulations in Romanian, IASB documents in English, UK law in English and French law in French are all original formal documents whose terminology can theoretically be regarded as official and automatically "correct". ${ }^{2}$ All other translations and word usages are the responsibility of the authors.

By way of an overview and framework we first present the key requirement in the Accounting law.

\section{$\underline{\text { Accounting law no. 82/1991 }}$}

Par 10: the official management document of the patrimonial entity is the balance sheet, which shall give a true and fair, unambiguous and complete view of a company's patrimony, financial position and results.

\section{- revised in 2002}

Chapter 1 General assertions

Par 10: The official documents for the presentation of the economic-financial position of legal person (or juridical person) in par. 1 are the annual financial statements, which shall give a true and fair view of the financial position, financial performance, cash flows and other information pertaining to the company's activity.

\section{- revised in 2008}

Par 9 (1): The official documents accounting for the economic-financial position of persons in par. 1 are the annual financial statements, established according to the law, and which should give a true and fair view of the financial position, financial performance and other information pertaining to the company's activity.

Par 30: The financial statements will be accompanied by a statement of the persons set in par. 10 (1) by which they assume responsibility for the preparation of the financial statements and confirm that:

a) the accounting policies used when preparing the financial statements comply with applicable accounting regulations;

b) the financial statements give a true and fair view of the financial position, financial performance and other information pertaining to the company's activity;

c) the juridical person is a going concern.

\footnotetext{
${ }^{1}$ In relation to the two versions of the Fourth Directive this statement is pragmatic nonsense. But the statement is explicitly correct under EU law.
} 
Several points are worth mentioning. Patrimonial entity (ro. unitate patrimonială, fr. unité patrimoniale) relates to a concept central to traditional accounting thought in many European countries and languages, including also Italy, Spain and Portugal, but at best incomprehensible in English (where patrimony relates explicitly to money received from one's dead father). It may loosely be thought of as the organisation which owns the assets (resources/money or money's worth). True and fair view (ro. imagine fidelă; fr. image fidèle) obviously translates the Romanian directly from the French. Balance sheet (ro. bilanţul contabil; fr. bilan comptable) really refers to the accounting statements (plural), as the wording of the law implicitly makes clear (see also Italian: bilancio). This usage ignores the Fourth Directive, available of course since 1978, which uses balance sheet (ro. bilanț; fr. bilan) in its narrow specific sense. The wording changes to annual financial statements (ro. situații financiare anuale; fr. états financiers annuels) in 2002.

Para 30 in 2008 is interesting. This reads in French, and the Romanian original, as follows. Art. 30. - Les états financiers annuels seront accompagnés d'une déclaration par écrit de personnes prévues par l'article 10 (1) par laquelle ils assument leur responsabilité pour l'établissement des états financiers et attestent que :

a) les politiques comptables utilisées pour l'établissement des états financiers sont conformes aux règlements comptables applicables ;

b) les états financiers donnent une image fidèle de la situation financière, de la performance financière et d'autres informations relevant de l'activité déroulée ;

c) la personne morale continue de dérouler son activité.

Art. 30. - Situațiile financiare anuale vor fi însoțite de o declarație scrisă a persoanelor prevăzute la art. 10 alin. (1) prin care îşi asumă răspunderea pentru întocmirea situațiilor financiare anuale şi confirmă că:

a) politicile contabile utilizate la întocmirea situațiilor financiare anuale sunt în conformitate cu reglementările contabile aplicabile;

b) situațiile financiare anuale oferă o imagine fidelă a poziției financiare, performanței financiare şi a celorlalte informații referitoare la activitatea desfăşurată;

c) persoana juridică îşi desfăşoară activitatea în condiții de continuitate.

Article 30.c) comes from Fourth Directive Article 31.1.a): the company must be presumed to be carrying on its business as a going concern: la societé est presumée continuer ses activités. Positive confirmation of this is required, unlike under IAS 1. But even more interesting about this paragraph is that the three requirements, a), b) and c), all have to be confirmed. The TFV requirement is not here, even in 2008, superior to recognised compliance with applicable accounting regulations. More detailed documents discussed below give a different picture.

The basic 1991 law requirement in para. 10 was supplemented by a government regulation in 1993. Key paragraphs from this regulation are as follows. 


\section{Government decision no. 704/1993 for the implementation of the Accounting Law no.}

$\underline{\mathbf{8 2 / 1 9 9 1}}$

Par 22: The official management document of the patrimonial entity is the balance sheet, which must give a true and fair, unambiguous and complete view of a company's patrimony, financial position and results.

In order to give a true and fair view of the patrimony, the financial position and results, one has to obey in good faith the rules concerning the patrimony's evaluation and the other accounting standards and principles such as: prudence, consistency, going concern, cut-off, sanctity of opening balance sheet, offsetting.

Par 141: In accordance with par 29 of the Accounting Law, balance sheets are reviewed and certified by censors, certified or expert accountants, accordingly.

By this review and certification of the balance sheets it is testified that they give a true and fair, unambiguous and complete view of the patrimony, financial position and results. In this respect, based on check-outs throughout the year and other items judged as necessary to draw reliable conclusions for the balance sheet certification, a report is prepared so as to state primarily:

- whether or not the balance sheet is drawn in accordance with accounting records;

- whether or not the accounting records are kept in accordance with corresponding regulations;

- that rules for patrimony's evaluation and the other accounting standards and principles are followed in good faith.

Par 142. The balance sheet is approved and published in accordance with the provisions of the law. The balance sheet may be published in a simplified form.

Par 143. Small and medium-sized patrimonial entities may prepare the balance sheet in a simplified form.

This pronouncement puts flesh on the bones of the 1991 para 10, clearly indicating that TFV is not superior to "the rules". These rules (ro. regulile privind evaluarea, normele şi principiile contabile; fr. règles d'évaluation, normes et principes comptables) listed in Article 22 are taken directly, all six of them, from Articles 31.1.a) to f) of the Fourth Directive. It is not clear where the phrase intangibilitatea bilanţului (l'intangibilité du bilan); tentatively translated as "sanctity of opening balance sheet" comes from. It seems to bear little relationship to its origin, Article 31.1.f), a requirement which seems superfluously obvious anyway:

the opening balance sheet for each financial year must correspond to the closing balance sheet for the preceding financial year.

le bilan d'ouverture d'un exercice doit correspondre au bilan de clôture de l'exercice précédent.

The reference to 'censors, certified or expert accountants' (ro. cenzori, contabili autorizaţi sau experți contabili; fr. censors, comptables autorisés ou experts comptables) relates to the 
previous communist system of having independent checkers of the form-filling (not auditors as the term is universally understood).

Pars 142 and 143 raise a problem. At first sight Para 143 allows SMEs to use a simplified form (ro. în formă simplificată; fr. une manière simplifié), and Para 142 allows all entities (by definition including SMEs) to use a simplified form for the balance sheet (equals financial statements here). Para 143 presumably relates to Fourth Directive Articles 11 and 27, allowing small businesses as defined to prepare an "abridged" (ro. simplificat; fr. abrégé) balance sheet, and to have specified income statement items "combined under one item" (fr. inclus sous un poste unique). The relationship between Para 142 and Para 143 is not immediately obvious.

Note however that 143 uses the word "prepare" (ro. a întocmi; fr. établir), whereas 142 uses the word "publish" (ro. a publica; fr. publier), which may be significant, i.e. non SMEs under 142 are required to "prepare" full accounts (being excluded from 143) but need not "publish"

full accounts. This analysis has been confirmed by one of our interviewees, and is consistent with the legacy of secrecy from the communist days.

The question could be asked as to whether simplified accounts are capable of giving a true and fair view. In principle the answer is unequivocally yes, but it would be a different true and fair view from that given by the full accounts (view supported by one of the representatives of the Ministry of Finance - i.e. Romanian regulator).

In 1999 the Romanian Ministry of Finance published an order (no. 403/1999) moving towards the Fourth Directive and IAS. This contained 3 volumes (all in Romanian) - national regulation, the IASC Framework, and the then extant IASs. This was developed and reissued in 2001, and we give only the latter in any detail.

\section{Order of the Minister of Public Finances no. 94/2001 (for the complete assimilation of the $4^{\text {th }}$ Directive and the carrying on of the harmonization with IASs)}

Section 3 - Annual financial statements of companies

3.3 Financial statements must give a TFV of the company's financial position, performance, changes in equity and cash-flows for the period.

3.5 To the extent that no relevant IAS exists, the managers will produce accounting policies in accordance with "The General framework for the preparation and presentation of financial statements" presented in Volume 2, and will make sure that financial statements present information that:

a) is relevant for decision-making;

b) is reliable in that it:

i) faithfully presents the results and financial position of the company;

ii) reflects the substance of transactions and not only the legal form;

iii) is neutral, meaning impartial;

iv) is prudent; and

v) is complete in all material aspects. 
3.7 When the accounting treatment provided in the 4th Directive differs from the one in the IASs, throughout the entire implementation phase of the accounting system development programme, companies may choose one of those two treatments, so as to give a TFV of the event under consideration.

3.8 Under special circumstances, should the observance of a provision in Volumes 1, 2 and 3 result in not giving a TFV, the company's managers may disobey these requirements as much as is necessary to give a TFV. Under such circumstances, the company has to present in the notes the following:

a) the fact that the managers have reached the conclusion that the financial statements give a TFV of the company's financial position, performance, cash flows and changes in equity;

b) the mention that the company has applied in all material aspects, the provisions of the Volumes 1, 2 and 3, except for what was necessary to give a TFV;

c) the provisions and standards from which exception was made, the nature of such exceptions, the accounting treatment required by the regulation or the standard, and the reason for which the accounting treatment required was judged as inadequate under the specific circumstances, as well as the accounting treatment adopted;

d) the financial impact of the exception on the company's equity, net income or loss, assets, liabilities and cash-flows, for all the disclosed periods.

Section 8 - Financial audit

8.2 The auditor will make sure that the financial statements are prepared in accordance with the Accounting Law no. 82/1991 as revised, and with the provisions of Volumes 1, 2 and 3, as well as the extent to which information in the Management report are consistent with the information in the financial statements prepared for the period, based on audit procedures in ISA 720.

The wording of all this seems to come from a combination of Article 2 of the Fourth Directive, and IAS 1 as then extant. It ostensibly brings in the TFV override, but with a crucial uncertainty. Para 3.3, supported by the emphasis in Para 3.7, says that financial statements "must" (ro. trebuie; fr. il faut que) give a TFV. However Para 3.8 says that preparers "may" (ro. se pot; fr. peuvent) depart from rules to give a TFV. The 1999 version was crucially different here, saying that preparers "will" (ro. se vor; fr. dérogeront, i.e. the simple future tense). The override in 1999 is therefore unequivocal. But what is the exact position in 2001 ?

Textual analysis of the 2001 Order suggests that the override is still definitely included. We support this statement in two different ways. The first is that Para 3.3 requires a TFV as the primary objective, and Para 3.8 tells companies what they can (may) do "as much as is necessary" (ro. atât cât este necesar; fr. tant qu'il est nécessaire) to achieve that (required and essential) objective. In certain circumstances, therefore, use of this possibility becomes obligatory. The second supporting argument comes from the teleological principle fundamental to a Roman law system. This says that interpretation and application of the totality of a set of regulations should reflect and support the purpose of the regulations. In this case, the purpose is encapsulated in the title of the order, so it follows that incorporation of the override of Article 2 (and IAS 1) was intended. 
These two arguments are both powerful, but cannot be regarded as definitive, because the Ministry can logically be assumed to have had some purpose in mind when making the change towards a looser wording in 2001. Only in 2005 does the override become absolutely unequivocal, as is clear from the following.

Order of the Minister of Public Finances no. 1752/2005 (Conformity with European $\underline{\text { Directives) }}$

\section{Section 1 General provisions regarding the annual financial statements}

Par 9. Financial statements give a TFV of the entity's assets, liabilities, financial position, profit or loss.

Par 10. If the observance of the present regulations is not sufficient to give a TFV within the meaning of Par 9, additional information must be presented.

Par 11. Where, in exceptional cases, the application of a provision of this present regulation is against the obligation explained in par. 9, that provision must be departed from in order to give a TFV within the meaning of par. 9. Any such departure must be disclosed in the notes, together with the reasons for such a departure and its impact on the assets, liabilities, financial position and profit or loss.

Thus a relevant provision "must be departed from" (ro. trebuie să se facă abatere; fr. il y a lieu de déroger) as far as is necessary to give a TFV.

This section of the paper has explored the regulatory framework in Romania regarding TFV over the last couple of decades. The route has taken us, at times unevenly and with deviations, from the mechanical attitudes of communist form-filling, combined with a formulaic, and arguably meaningless, incorporation of the words TFV, through to the de jure unequivocal inclusion of the requirements of Article 2 of the Fourth Directive. The concept (signified) represented in Romanian thinking by the words (signifier) can be expected to have changed. This does not for a moment imply, however, that former associations will have disappeared. We now turn to our empirical investigations which seek to explore and analyse current attitudes and perceptions by actors actually involved in regulation and practice in Romania.

\section{PERCEPTION OF TFV IN ROMANIA}

In order to explore the attitudes toward and perceptions on TFV in practice, we interviewed 9 actors involved in accounting regulation and practicing in Romania, that is preparers, auditors, professional bodies and the national regulator. It is important to emphasise that our selection of interviewees does not represent 'a sample' in any normal statistical sense. They were not randomly chosen and are not statistically-speaking 'representative'. They are, however, something much more important, namely the major decision-takers and opinionmakers in, collectively, the major functional roles relating to financial reporting in Romania. 
We are not, formally, in a position to claim that the opinions and arguments expressed are 'typical'. But we are certainly in a position to claim that the opinions and arguments expressed matter, both in theory and as regards practical outcomes, in Romania. In line with the suggestions made by one of the AFC congress reviewers, in order to have a more complete picture of this process, we intend to subsequently interview several representatives of the users' group (i.e. investors and creditors), but none has been conducted so far. A future revision of this paper will definitely include several such interviews.

The interviews lasted from a minimum of 45 minutes to a maximum of 75 minutes, with a mean of 57 minutes. The majority of interviews were conducted at the workplace of the interviewees, with two interviews conducted at the Bucharest Academy of Economic Studies. Appendix A details the list of interviewees, the exact date and duration of the interviews. All the subjects are Romanian citizens, have Romanian as mother tongue and are based in Bucharest. The interviews were carried out in Romanian, in order to capture the nuances, to allow a more fluent course of the discussion, and to ensure the consistency of interviews, even if some of the interviewees were at ease with English as they studied and practice this language on a daily basis at work. Some of the interviews were recorded on tape; when permission to record was not granted by the interviewees, notes were taken during the interviews, with immediate transcription after the interview. The interviews were semi-structured in the sense that the authors have decided in advance on some topics (questions) to be covered during the interview. During the interviews, a willingness to share the experience was shown generally; however, for various reasons, some of the questions remained unanswered or ambiguous answers were given. ${ }^{2}$ As regards the questions, the interviews contained several questions which were common to all groups, while others individualized to address specific issues according to each of the groups. We consider that given this construction of the questionnaires, we assured a common ground for discussion while still being able to capture relevant aspects pertaining to the specificities of each of the interviewed groups.

The issues related to TFV concept covered during the discussions concerned the translation, the meaning (perception) and the operationalisation of the concept, TFV override, and the perceived future evolution.

\subsection{Translation issues}

TFV was included in the Romanian legislation using a translation via French: 'imagine fidelă' (fr. image fidèle; en. faithful image ${ }^{3}$ ). Given the discussions generally raised by the translation issues (see Alexander, 1993; Sucher et al., 1996; Kosmala, 2005) and particularly by the French translation (Alexander, 1993; Burlaud, 1993), we investigated whether a translation by two words instead of one would not be more closely related to the original meaning of TFV. Two of the preparers had no opinion regarding translation, but P3 linked the translation to the meaning of TFV:

\footnotetext{
${ }^{2}$ For reasons of space, we do not append the proposed questions. They can be obtained from the authors.

${ }^{3}$ This is in line with Alexander (1993) and Burlaud (1993), translating 'image fidèle' by 'faithful image'.
} 
"Personally, I hope I understood what TFV means... I do not think that the wording (translation) is to blame, it's the explanation. 'Fidelă' means not only obeying to the rules. The problem is that it is a concept that we totally ignore, therefore I personally believe that a different wording would not have had different meaning."

A1 supports the same opinion; a Romanian specific wording would not have changed the concept, its application or perception. A2 also considers the meaning more important than the wording:

"The Ministry of Finance took the French approach because our legal system is closer to the French one. But the majority of practitioners do not care that it is taken from French at all, they apply OMFP 1752 and that's it. For large companies where TFV actually matters, they are already influenced by the British accounting culture."

For regulators it seems normal to take the French translation, and R2 argued that "as long the term exists and it is used by so many others, I do not see any reason to invent a new one". Concluding, the interviewees agree that the translation of TFV in Romanian language is adequate and is not the primary factor that affects its perception. More, it is not a debatable topic, because all were more interested in discussing the meaning of this concept, not the wording. This is quite an interesting difference from other countries where translation issues appeared. For example, Kosmala (2005) shows that in Poland there is a multiplicity of translations and grammatical constructions for TFV, and differences exist between different actors regarding the preference for one or two-word translation.

\subsection{Perceptions on TFV}

Romania has been influenced (or counselled) by French and British experts in different waves of the accounting reform. Generally, academics agree that the first stage of the reform was based on the French model, with a swing towards the Anglo-Saxon model through the IAS implementation after 2000 (Ionaşcu et al., 2007). But both the representatives of the national regulator we interviewed underlined that Romania never used the French system or the Anglo-Saxon one, it was always the $4^{\text {th }}$ Directive and sometimes some treatments from IAS are/were included in the national legislation because the World Bank demanded so. In this context, we explored the perception (meaning) on TFV of different actors. We agree that "a concept developed in one culture cannot simply be transferred or extended to another without alteration in its implications" (Alexander, 1993: 60). We aim here to investigate the way these successive waves of reforms reflected into the current perception on TFV.

We expected to find different perceptions on TFV given the categories of actors interviewed. But even the overall understandings of TFV are very different. R2 considers TFV as "mainly a theoretical concept, which is not very well defined in literature", and PB2 states that "the concept of TFV has no definition". Yet, A1 sees TFV as "the Pater noster prayer" for auditors, A2 considers TFV "as a guiding principle", and PB1 indicates TFV as "a vital concept for the auditors". Quite interestingly, A2 added that "it still is something too theoretical to many, but they will come around". Also, we may mention that none of the three preparers was able to clearly articulate their view on TFV. 
R1 perceives financial statements as "constructions of reality based on a particular context" and explains that when TFV was firstly introduced in Romania, he insisted on the use of the particle 'a' (" $a$ TFV") (ro. $o$ imagine fidelă; fr. une image fidèle).

The auditors interviewed perceive TFV through the users of financial statements. For A1, "giving a TFV means that the financial information gives to users an image of the reality of transactions for decision making" and "for the auditor, TFV means significant for the client... my actual clients are the users and the shareholders". For PB1 and PB2, the professional judgment is fundamentally linked to TFV.

As regards synonyms or equivalent terms, R2 hesitated to give one, but considered TFV different than "correct" (ro. corectă, fr. correcte) and "true" (ro. reală, fr. réelle). He underlined that TFV does not mean "correct presentation" (ro. prezentare corectă; fr. présentation correcte) because it is difficult to use the word 'correct' when dealing with a lot of estimates. Also, he argues that the concept is not similar to "true" (as in 'true financial statements') (ro. situații financiare reale; fr. états financiers réels) as "we suppose that they are true since they are prepared and signed". A2 perceives the TFV concept closely related to substance over form and considers that privileging form over substance is the "greatest threat to TFV in Romania":

"Question: We see that you come back over and over again to Substance over Form. Is that what TFV means to you?

Answer: No, it is the primary threat to TFV in Romania. I see TFV as depending heavily on professional judgment. Unfortunately, instead of leaving people to use principles and apply professional judgment, we continue to give rules; it is as if the Ministry of Finance still wants to control everything, it is as if we still were in a planned economy. Sometimes, the rules of the Ministry of Finance can make a set of financial statements completely irrelevant."

We may relate this assertion to the issue of principle- or rule-based accounting systems, as raised by some of the interviewees. Regarding the accounting culture that underlies the concept, R2 noted that French accounting system is more secluded, more prudent, but they did not have big scandals; the Anglo-Saxons have more permissive rules, and they had scandals. However, A2 made some comments that contrast this point of view:

"While US GAAPs are rule-based, IASs are principle-based. US GAAPs come from a tradition of accounting where people were forced to obey legal provisions and rules... If someone went around that rules, they changed the rules; consequently, someone found another way to go around the rule. This lead to Enron, Worldcom, Lehman Brothers and all these current bankruptcies. Therefore IASs, very much British inspired, principle-based, based on professional judgment, got the upper hand... Romania has to apply IASs, but they are applied in our country in a unique approach - very close to the American way, that is we make a set of rules".

PB2 has a different opinion regarding this issue:

"It is an issue here that will not be solved soon enough internationally - rules or principles. It is a fundamental issue, based on the law system. We do not know if one of them is superior to the other. I always say that we have to combine appropriately the two systems: 
good principles with plain rules of application. If you leave it only up to principles, TFV becomes an individual matter: each of us has his own TFV of something. I don't know if it's good or bad. Conversely, it applies to rules: why should anyone set a rule to be followed by everyone?"

In France, TFV is closely related to regularity (conformity) and sincerity ${ }^{4}$ (fr. regularité et sincerité; ro. conformitate cu regulile şi sinceritate) (Alexander, 1993; Burlaud, 1993) and even in some Anglo-Saxon ${ }^{5}$ accounting systems compliance may be considered a fundamental element of TFV (see Alexander and Jermakowicz, 2006; Kirk, 2006). For PB2, TFV "is strictly related to two qualities of accounting: regularity (conformity) and sincerity. You may most definitely say of accounting which is regular in form and fair in substance, that it is faithful or that it faithfully represents reality." Regarding the regularity issue, the opinions were contrasting even among the same category of actors. P1 and P3 consider that TFV does not mean only compliance with the rules, while P2 underlined that in Romania TFV means exactly that. PB1 distinguishes the perception on TFV based on two types of audit companies: Big Four and other multinational network firms and Romanian audit companies. He considers that the two segments are quite different in Romania, and that for Big Four and other multinational network firms TFV is "clearly something else than regularity (conformity) and sincerity, because they are focused on the needs of their clients... they conceive TFV related to the materiality concept".

The regulator's opinion was that regularity (compliance) is necessary, but it may not be enough. Actually, R2 made three interesting and somehow contrasting affirmations:

"a) I am interested not only in obeying the rules, but also in giving a correct picture.

b) Companies must account for all the transactions in accordance with their substance, and secondly to obey all rules of preparation, measurement and presentation of financial statements.

c) As regulations are conceived today, companies have enough provisions and flexibility to present fairly (ro. să prezinte fidel; fr. presenter fidèlement) their activities."

At a first look, we might conclude that the regulator is not only interested in the compliance with the rules. But the phrase "account for all the transactions in accordance with their substance" is quite debatable for two reasons: it does not mention "economic substance", and secondly, OMFP 1752 demands that the substance over form principle "is used by the companies mentioned in par. $3.1^{6}$ in statutory and consolidated financial statements, and by the companies mentioned in par. 3.2 only in consolidated financial statements". Of course, the last affirmation shows that the law is sufficiently detailed and flexible in order to assure TFV. In a logical analysis of priorities, we may force the following analysis: A. the most important

\footnotetext{
${ }^{4}$ For a detailed explanation regarding these concepts, see Alexander (1993) and Burlaud (1993). For the aim of this paper, we mention two ideas of these studies: (1) In France, 'régularité et sincérité' existed in the national regulations before the $4^{\text {th }}$ Directive enactment, which simply added a third concept, 'image fidèle'; (2) for some, régularité et sincérité means TFV, but the authors agree that there are cases in which régularité et sincérité are not sufficient to give a TFV, so régularité et sincérité do not automatically result in giving a TFV. It should be emphasised that our English words, regularity and sincerity, as used here, are literal translations of concepts only understandable in their native context.

${ }^{5}$ There are significant differences between USA, UK, Australia, New Zealand etc., but these countries are generally considered as Anglo-Saxon accounting culture.

${ }^{6}$ These are the companies that may be labelled as big companies; the others are SMEs.
} 
is the "correct picture" according to the substance, followed by rules application; B. the rules are conceived to give, if applied, a correct picture. This reasoning comes to validate other actors' view, that the regulator expects compliance and that the rules application is enough. In the same line, PB1 noted that "The Romanian Ministry of Finance still sees OMFP 1752 as a means to obtain a TFV through a correct application of the provisions of the law", or "a fiscal view" as noted by PB2.

The auditors also consider TFV as linked to a certain extant to the compliance rule, A1 showing that "financial statements give a TFV in respect with the framework used to prepare them". A1, A2 and PB1 consider that from the auditor's point of view, TFV and fair presentation (present fairly) are equivalent concepts, because ISAs allow both wordings. However, A2 observed that "TFV is larger than fair presentation... I think statutory accounts only present fairly."

It is interesting to note that in the previous acts the wording used was " $m u s t^{7}$ give a TFV" (ro. trebuie să ofere o imagine fidelă; fr. il faut que les comptes donnent une image fidèle), but in OMFP 1752/2005 the word "must" (ro. trebuie) does not appear anymore. R1 argued that the law commission insisted to eliminate the word "trebuie" from the Law since all the laws are mandatory. R2 also noted that even if "trebuie" has disappeared, the meaning is the same because the idea of compulsoriness still exists: "give" (ro. oferă; fr. donnent) is imperative, it does not mean "may give" (ro. pot să ofere; fr. peuvent donner). PB2 ironically noted that "they (the regulations, N.A.) are so well designed that they (financial statements, N.A.) 'give' without any doubt..." A concern may be expressed here (and will be confirmed later on) regarding this, as the wording of the Ministerial Order may be interpreted as "provided that the financial statements are prepared in accordance with the provisions of the Order, they give a true and fair view ${ }^{8, "}$ beyond any doubt, which is inconsistent with the override provisions both in the 1752 Order and in the $4^{\text {th }}$ ED (even though not existing in the Romanian Accounting Law no. 82/1991 with revisions). In support of this concern, it emerges from discussions the Romanian co-authors of this paper had with an esteemed Romanian commercial law academic that strictly from a legal point of view, the distinction between 'must give' and 'give' has no immediate implications, as 'both of them are indeed imperative', thus supporting the view of R2 stated above in section 2. Yet, two comments can be made:

- firstly, the same commercial law Romanian academic interestingly notes that:

"The choice between "must give a TFV" and "give a TFV" has a very strong political connotation:

- If the legislator wants to underline which are the obligations that the law subjects have, then he will use the verb "must";

- If the desire is just to explain why a certain economic category is used then, the verb "give" has enough resonance for that (for example, I understand that the legislator explains me that "TFV" is more useful for me because it gives me a complete view of the economic situation of a legal person instead of another procedure that I can use to register the same business operations)."

\footnotetext{
${ }^{7}$ Our italics.

${ }^{8}$ Our italics.
} 
It follows from here that in fact through the wording used here the regulator merely explains "why a certain category is used", while it should have "underlined the obligations that the law subjects have". This interpretation also has the support of our Romanian business law academic, obtained during a follow-up discussion;

- secondly, we may assert (based on the interviews we have conducted, and on other professional discussions with accounting colleagues) that while this distinction may not be of immediate implication from a legal point of view (as per the first remark), it may very well induce bias into the perception of accounting professionals and managers. Due to a limited knowledge of legal matters, they may interpret it as we did (i.e. "provided that the financial statements are prepared in accordance with the provisions of the Order, they give a true and fair view"), with the (tacit) consent of, and in line with, the intent of the Romanian regulator (Ministry of Finance).

Another comment may be worth here. It regards the wording in the Romanian official translation of the $4^{\text {th }} \mathrm{ED}$ (as published as an appendix to the OMFP 1775/2004 ${ }^{9}$ ), as presented below:

Întrucât conturile anuale trebuie să ofere o imagine fidelă a activelor şi datoriilor, poziției financiare şi a profitului sau pierderii societății comerciale;

Art. 2

3. Conturile anuale oferă o imagine fidelă a activelor, datoriilor, poziției financiare şi a profitului sau pierderii societății comerciale.

considérant que les comptes annuels doivent donner une image fidèle du patrimoine, de la situation financière ainsi que des résultats de la société;

Art. 2

3. Les comptes annuels doivent donner une image fidèle du patrimoine, de la situation financière ainsi que des résultats de la société.

Whereas annual accounts must give a true and fair view of a company's assets and liabilities, financial position and profit or loss

Art.2

3. The annual accounts shall give a true and fair view of the company's assets, liabilities, financial position and profit or loss.

It is self-evident that the wording of the first sentence comes from the preamble to the Directive, while the second sentence is part of the text of the Directive itself. On close examination, there is considerable inconsistency here. The Romanian uses 'trebuie' in sentence 1 and 'oferă' in sentence 2, i.e. 'must give' (imperative) and 'gives' ( officially simple present tense) respectively. The French uses 'doivent donner' (strictly translated as 'should give or ought to give') both times. The English uses 'must give' (imperative) and 'shall give' (future instruction) respectively. It is reasonable to suggest, at least tentatively, that the English 'must' and 'shall' here have identical implications: i.e. doing it cannot legally be

\footnotetext{
${ }^{9}$ We base our analysis on the official translation of the $4^{\text {th }}$ ED in Romanian as published into the Official Journal of Romania in 2005. An official European Union version of the $4^{\text {th }} \mathrm{ED}$ was also published in the EU Official Journal, after January $1^{\text {st }}, 2007$, when Romania adhered to the EU. It uses the same wording regarding the TFV, except for the use of the wording "a patrimoniului, a situa $\square$ iei financiare etc." instead of "activelor, datoriilor, poziției financiare" etc. as used in the Romanian official translation.
} 
avoided. The use of identical French words in each sentence tends to support this proposition of identical meaning in the 2 English sentences. This analysis further supports the proposition that the French wording, despite the fact that 'doivent donner' is less strong then 'il faut qu'ils donnent', also clearly states that 'doing it cannot legally be avoided'.

But the Romanian seems more problematic. The mandatory power of the wording in the first sentence is certainly retained (must give/trebuie). But the clear instruction (at minimum) of the second sentence in both English and French is arguably lost in the Romanian translation (using the simple present tense, ro. oferă). This 2004 translation seems to be at the origin of the 2005 wording in OMFP 1752 regarding the objective of financial statements. In our view, the present tense phrasing used in Romania (ro. oferă; fr. donnent; en. give) leaves the door open to (mis)interpretations, and should be changed into a more compulsory-like one. We return to this issue in section 4.

In a previous study on perceptions on TFV, Kirk (2006) identified a list of terms usually associated with TFV: absence of material errors, accurate and correct, compliance, corresponds with proper professional judgments, correspond with economic substance, fair, fair presentation, full disclosure, not misleading, objective, relevant and useful, and true. In Romania, we noticed differences regarding the categories of the interviewees. For auditors and professional bodies, TFV is closely related to professional judgment, to the economic substance and to the relevance and usefulness for users. Given the ISAs, the auditors consider that TFV and fair presentation are synonymous. Generally, the preparers and the regulators consider that compliance with the law is the most important consideration for giving a TFV. These issues will be developed by an analysis regarding the operationalisation of TFV and the TFV override.

\subsection{TFV operationalisation}

The context of TFV is given by the accounting framework (principles, rules) and the role of different actors in this process. Firstly, we will discuss the Romanian accounting system in order to see if the rules and the principles are to reflect the economic reality and lead to not misleading, relevant and useful financial statements. Also, we will refer to the evolution of the Romanian accounting system, which demanded to a large extent the application of IASs between 1999 and 2005, with a focus on the $4^{\text {th }}$ Directive after 2005. The interviewees perceive differently this change and its implications. The regulator's representatives insisted on the fact that IASs were imposed in Romania because of the World Bank pressures. According to R1, in 1997-1998 the World Bank imposed 4 conditions for granting its assistance: the use of IASs by some (generally large) companies, the auditing of these companies by auditors applying ISAs, the issuance by the Ministry of Finance of a guide for IASs implementation, and the establishment of an institution for financial auditing (thus the Chamber of Financial Auditors of Romania). However, R2 admits that:

"There was a trend of application of the IASs in order to attract foreign investors and to develop the financial market, but we learned that IASs were very difficult to apply, to understand, involved large costs of application and fiscal risks for companies as accounting and financial statements were also used to determine taxes... Therefore, along with Romania's adhesion to EU, we have secured the conformity with the $4^{\text {th }}$ Directive: 
everything that is compulsory in the Directive is taken in the Romanian regulations, and also some optional provisions were taken. Where the Directive had basic provisions or such provisions were completely missing, we took the IASs provision, but only to the extent that these provisions would not be against the provisions of the Directive."

OMFP 1752 is considered by A2 and PB2 as a step back in IASs implementation in Romania, while the opposite is expressed by P1 and R2. PB2 underlines that "these ${ }^{10}$ are two parallel worlds". R1 admits that OMFP 1752 still has some unresolved issues, such as the lack of details regarding impairment tests. In the same line, A1 argues that the order "is short of a socalled $2^{\text {nd }}$ set of details, explanations, which would really allow comparability of financial statements" citing three such examples: impairments tests, deferred tax, and financial instruments.

The issue of deferred tax was also addressed with all the interviewed persons. The following interesting discussion may be prepared based on some of the comments:

Preparer (P1): our company prepares financial statements for consolidation according to IASs and we strived to get the two sets of accounting rules as close as possible. Still, some differences exist, as for example deferred tax."

Regulator (R2): "In OMFP 1752, a 'provision for taxes' exists to solve the problem of deferred tax".

Auditor (A2): "But what about the asset? We only recognize the liability... It is not fair. And what about deferred tax which should be recognized in owner's equity? They are covered by this provision".

Regulator (R2): "We only took the liability and not the asset, as the standard is also prudent in the recognition of the asset".

Preparer (P1): "We used deferred tax in the first year, but there were discussions with the Ministry of Finance and we gave up."

Regulator (R2): "Companies do not want to account for such provisions, as it involves an expense and a liability, and it reduces profits."

Preparer (P1): "Even if such a provision exists in the legislation, details regarding the recognition are needed because we are accustomed to have laws as descriptive as possible."

Regulator (R2): "We will not implement under any circumstance IAS 12, it is very difficult in itself to understand, even by the ones already using IASs".

We consider this picture as representative for the Romanian accounting system, in which the regulator tentatively gives some "space" to preparers, but given the accounting settings, the preparers usually only obey to the rules.

Under these circumstances, our next question is whether the application of OMFP 1752 generates financials statements that give a TFV. The views are contrasting ones. Not surprisingly, R2 thinks that to the extent that companies obey all the provisions of the Order, the financial statements prepared give a TFV. Yet, P3 says that companies that do not apply IASs and only prepare financial statements according to Romanian legislation, do not give a $\mathrm{TFV}$, because "there are a number of loop holes, the companies only want to obey the

\footnotetext{
${ }^{10}$ OMFP 1752 and IASs (n.a.).
} 
provisions of the law and do not interpret the law, do not apply the law in its spirit". A2 gives some examples of issues to support his opinion that financial statements established according to OMFP 1752 do not give a TFV: lease contracts classification, financial instruments, the accounting treatment for investment properties, employees' benefits, deferred tax. PB1 adds some more: the use of LIFO and the accounting treatment for buildings bought for resale. In this context, he is aware that for the previous year, some auditors avoided to issue an opinion that financial statements gave a TFV, using the wording "present appropriately" (ro. prezintă adecvat) maybe in order to avoid legal responsibility, as there may be a possibility they did not believe that financial statements prepared according to OMFP 1752 gave a TFV ${ }^{11}$. Also, PB2 considers that financial statements established according to OMFP 1752 do not give a TFV:

"They are false and we cannot talk about accounting in the best interest of the national economy, due to the regulations. We do not have standards, we have regulations. Who issues regulations? It is the State, in its double capacity: regulator and user of its own regulations. It cannot be 'clean'. The State is only interested in the fiscal duties. Therefore, the 'poor' balance sheet (which should normally present information for all the users) according to 1752 , is in fact misleading for everyone else, in respect with the three large amounts: non-current assets, inventories and receivables. Only one is totally satisfied: the State. As regards non-current assets, everyone uses depreciation schemes according to legal regulations (which is a catastrophe). 1752 has the biggest reform in accounting since 1990, but unfortunately it was not observed by the business environment or accountants: it is the first regulation allowing the use of useful life when establishing depreciation schemes. Unfortunately, companies still use legal schemes. As regards inventories, the tragedy is even bigger. When adopting the accounting law, we have fought to make the regulator force companies to compute write-downs for these items. Finally, they went for "they can" writedown. Accordingly, accountants do not compute it. Accordingly, owners said: 'OK, the state is computing profits on a fictive income. Therefore, why shouldn't I get dividends from the same fictive income?' As regards receivables, one should use certain rules for adjusting the value of these items... We present this balance sheet but it is false. We cannot speak therefore about faithfulness. It only is the fiscal image of the company."

He concluded: "We have fictive financial statements to the highest extent ever; they do not represent at all the reality". Maybe aware of all these issues, A1 consider that financial statements prepared in Romania give a TFV "in respect with the framework used to prepare them", admitting however that:

"Romania is an emergent country. Even if surpassed the transition phase, we come from a period of sustained economic growth when the financial information did not really matter.

\footnotetext{
${ }^{11}$ Still, in a recent follow-up discussion with PB1, it seems that the phrasing which will be used for the financial statements drawn up as of December 31, 2008 will change following a large consultation between the CAFR and auditors acting in Romania. The current version of the opinion would supposedly employ the wording "give a TFV in all material aspects of the entity's financial position as of December 31, 2008, as well as of its financial performance and cash flows as of the same date for the financial year ended on this date in accordance with the OMFP 1752/2005 with revisions and with the accounting policies explained in Appendix 6 to these financial statements". In PB1's view, while not raising any more concern regarding the extent to which applying the OMFP 1752 results in the giving of a TFV, this phrasing reflects precisely that the auditors understand by performing an audit based on OMFP 1752, to check what the OMFP reflects of TFV.
} 
Accordingly, we may find anomalies here that anywhere else in the civilized world would not be found".

Some of these 'anomalies' are to a certain extent acknowledged even by the regulator. R1 says that many companies actually do not apply its provisions entirely, giving two examples: small companies that do not have the resources to correctly apply the order to the full, and large but not competitive companies, State-owned, which would have to be declared bankrupt if they applied the order to the full, yet the State supports them. P3 admits that "it is very difficult to discuss TFV especially for small companies":

"I have worked in a practice firm which kept accounting records for 22 companies with different characteristics. It is all about reducing taxes, not paying VAT, obtaining a balanced trial balance, and handing in various forms/statements in the legal terms... Also, I am aware of a case of an expert accountant who prepared different trial balances according to the bank where the company went for loans."

P2 underlines that financial statements prepared in accordance with OMFP 1752 "do not present clearly the financial position of a business; if someone wants to engage in doing business, they have to require a lot of supplementary information". In the same line, P1 says that "We focus extensively on notes because they offer a lot of information to supplement the balance sheet and the income statement". Also, A2 notes that "I do not believe that there is anyone conducting an analysis based on statutory accounts".

Regarding the role of different actors in giving a TFV, we consider that the size of the firm and the users do matter. The auditors offered the "big picture" of this mechanism:

"Basically, financial statements exist to offer information. Of course, the question is: who is the primary user of this information in Romania? In the Ministry's (n.a. of Finance) opinion, it is the Ministry. Honestly, as they are now conceived, the financial statements in Romania are primarily intended for the use of fiscal authorities." (A2)

"The users' needs are important. If the users are diversified and ask for qualitative information, this quality becomes important; if the company has only one user - the shareholder, he will not be interested in TFV but in the cash it generates." (A1)

We will analyze these statements through the specific context of the three preparers interviewed. P3 now works in a company for which "the only users are the owners and the State". "They told us to have this amount of profit, this income tax, and we have to manage with the rest..." As regards the accountants, he says that "they are not very concerned about giving a TFV. It does not matter that what we prepare is irrelevant, because it is actually irrelevant". The users are apparently the most important actor involved in this process. For him, "if no one asks for more, why do differently? If banks grant me loans with these financial statements, why do anything else?"

P1 works in a big company, controlled by a listed company on Frankfurt Stock Exchange, and prepares financial statements as close as possible to IASs requirements. Also, financial statements (both statutory and for consolidation purposes) are audited by one of the Big 
Four $^{12}$. His company computes value adjustments due to IASs requirements even if nondeductible for tax purposes. In this context, he makes two interesting remarks:

"Our company uses extensively IASs as also auditors insist on using them even if the reporting is in accordance with Romanian accounting standards. Still, the fair presentation depends extensively on the preparer and the extent to which he wants to reflect fairly, because it relies heavily on many assumptions the preparer uses".

More, P1 explains the implication of the actors in this process:

"The Ministry of Finance cannot say that companies do not reflect fairly the financial position as they do not know the internal reality of the business. Auditors can attest it because they know the reality of the business. Users employ the opinion of the auditors even if the auditors use disclaimers to avoid legal responsibility. The auditors' opinion stands for the credibility of financial statements and users rely on this because third parties cannot know the reality of the business."

P2 works in a large firm, but for them fiscal issues and the owner's requirements are very important. Regarding taxation, they consider that fiscal controllers come only to penalize them, and that it is an illegal competition in their sector because small companies do not pay all their taxes or do not record all the wages, thus "stealing" customers and employees away from companies paying taxes. As regards this matter, P3 put it very clearly: "it must be something wrong with the fiscal system since we (n.a. accountants) are this interested in the fiscal matters, and do not have the time to do anything else".

Regarding the auditor's involvement, R1 shows that "in Romania the responsibility of the auditors is limited, as they rely heavily on the work of other experts, while in the USA the auditors are entirely responsible for the work performed by others too". A2 gives the example of impairment tests:

"in practice, they (companies, NA) use valuers. These valuers use (rule-based) methods, and choose (based on their professional judgment) which method to apply. I don't think it is a matter of value in use, it is more about the market value. No one computes the value in use, based on discounted cash flows etc. In practice they use corrections starting from the value in the valuer's report. The valuer is a member of the National Association of Romanian Valuers (ro. Asociația Naţională a Evaluatorilor din România), therefore the value he gives you is all right. Auditors are usually prudent: for them, the larger the amount of the adjustment, the better. Therefore, if an asset is impaired to a smaller amount, it is ok. The image is distorted, but for auditors is ok".

It appears that this was precisely the intent of the regulator. R2, referring to the methodology for the impairment tests which is missing from OMFP 1752, even declares:

"The Ministry does not intend to change the methodology for the computation of such impairment, as it is made by 'persons knowledgeable of the domain'. More, taking the inventory and measurement is the whole responsibility of the company's management".

\footnotetext{
12 It is probably worth noticing that in the case of this company, 'both internal and external auditors are appointed by the parent company. We do not negotiate the fee, or anything else. They are therefore in a privileged position because we cannot influence the contract whatsoever'.
} 
PB2 considers that auditors "should be the guardians of TFV to make sure that no unfaithful information goes to the users", but he is somehow sceptical:

"Unfortunately, since in the Romanian regulation there is an enormous amount of inconsistencies and errors (it is even against the $8^{\text {th }} \mathrm{ED}$ ), we have only problems. The audit now is not even the control as made by censors before. Auditors give a clear report even if they have not participated to inventory takings. They do not understand the concept of audit. They have to know very well accounting before conducting audit."

PB1 considers that the role of auditors equals the role of preparers in giving a TFV, because if accountants and managers have the incentive of being "biased", the auditor is called to increase the credibility of financial statements. P1 considers that "the role of auditor is extremely important especially when it's about one of the Big Four. They do not depart from their principles, while Romanian audit companies are more willing to do so". R1 also acknowledged the role of Big Four, showing that "banks are audited by one of the Big Four, therefore they prepare some more reliable financial statements".

The administrators and managers have also a big role, but according to $\mathrm{R} 1$ the problem is that they are not properly trained and they do not help companies. He suggests that an institute for their training may be created, as exists in Egypt. However, according to the Romanian Accounting Law, managers have to sign a statement that financial statements they prepare, give a TFV. Yet, most of our interviewees said that "they sign because they have to." PB2 even says that they are not unconscious when signing this statement, "unconscious are the ones proposing this statement. They are the ones unconscious; they do not know what TFV really means."

In order to assess the importance of TFV, we asked if the concept is important only for the presentation of financial statements or it is also linked to the elaboration of accounting policies. R2 states that:

"It most definitely involves the elaboration of accounting policies. The financial statements are the consequence of accounting policies used, and to give a TFV means in the first place to have accounting policies adapted to the activity".

P1 and P3 also underline the importance of TFV for selecting accounting policies. PB2 considers that accounting policies should be used correctly and in good faith. A1 advances the discussion:

"TFV applies not only to accounting policies; it represents much more than that: it has an impact on the organizational culture of the business, on the information system of the company as preparers need to be able to gather data; it has an impact on the internal control system. Preparers all around the world, including Romania, do not fully understand the seriousness of not giving a TFV, and that TFV is not a simple problem of the 'poor' accountant." 


\subsection{TFV override}

TFV override is included in Romanian legislation as it is present in the $4^{\text {th }}$ European Directive. R2 admits that "I know it exists in the Directive, therefore we also took it. We cannot remove it, but probably a very limited number of companies will make use of it; it is to be applied only in extremely exceptional circumstances". Except for A2, all the interviewed people were unaware of examples of TFV override, and each actor has his opinion:

Regulator: "TFV should be extremely well justified and explained... It is highly unlikely that the accounting regulation does not comprise a provision for the specific case companies might want to refer to when trying to override the provisions of the law." (R2)

Preparers: "we would not under any circumstance depart from a provision of the law because the accountant is afraid to make an exception (diversion) to the rule. Who protects him from the controls he might have? How will he justify this exception?" (P2); "It is very difficult to prove, therefore I think people stand aside from engaging a conflict with the fiscal controllers" (P3)

PB1: "The Ministry still sees the OMFP 1752 as a means to obtain a TFV, as a correct view from the viewpoint of the observance of the provisions of the law. Accordingly, such cases of override are probably seen as inappropriate in respect of their goal."

A2 provides some examples of TFV override, because he considers that financial statements prepared in accordance with the provisions of the law (OMFP 1752) do not give a TFV, and the auditors demand adjustments. One example of TFV override is mark-to-market valuation for the stocks held by Financial investment companies (ro. Societăţi de Investiţii Imobiliare SIF). In Romania, only the banks are supposed to apply mark-to-market, but the auditors force the Financial investment companies to apply this principle in order to not distort the income statement.

Again, it seems to be a difference between companies from the point of view of the auditor. A2, P3, R1 and PB1 all distinguished between companies audited by Big Four and the other companies, and to a different extent, they consider that the auditor may influence the accounting policies used, and even impose a TFV override. A2 argued that "Romanian audit companies do not have the authority/force to impose such treatments to the same extent as the Big Four (they have financial power, prestige)".

PB2 puts the override under a different perspective:

"They (the regulators, N.A.) have introduced this for nothing. They have 'burned' a very important phase: we have to distinguish between standards and regulations (law). Standards are issued by non-governmental bodies, and are not compulsory. If I want to depart from a standard, I can depart, but I have to say why and what the consequence would have been if I applied. The regulations are issued by governmental bodies, and are compulsory. Therefore, the Ministry of Finance (issuing regulations) says: 'you may depart from', but if I go to court, I am being judged against the regulations. I always proposed to elaborate national standards mostly based on IASs, as Poland or Hungary do." 


\subsection{Future of TFV}

In this context of different perceptions on TFV, we also thought of the future of TFV. PB2 noticed that "it is possible to speak more about TFV once we have joined the EU." R1 and R2 both said that the concept will be kept in the Romanian legislation, but we demanded ourselves if its perception will change and which the potential drivers of this change might be. A1 insisted that "we have to understand that Romania comes from a period of time (the communist one) when all that was of interest was to 'report the over fulfilment of the plan', not the financial information. As long as this way of thinking still will exist, TFV will be of little interest." In the same line, PB1 considers that the change will be slow, because "the concept is embedded into the minds of people". Also, when asked during courses what TFV means, professionals immediately answer "obeying the law".

When referring to the change process, A1 considers that it is "pushed by the market". A1, A2 and R1, PB2 agree that "the needs of the users are important", while P1 believes that the "Anglo-Saxon spirit becomes more and more important due to multinational companies" and that "the perception on TFV evolves because of the intent of the preparer". P3 advances that "if the accountant would have more time, he would think more about TFV (at least this is what I hope)". However, PB2 thinks that "as long we have regulations and not standards, we will not have TFV".

Some of the interviewees refer also to a learning process. PB1 considers that the concept should be explained better, and gives the example of the Chamber of Auditors which after its creation in 2000 explained it in the courses for auditors. Also, as a professional body, ACCA is considered by the auditors (A2) as having an important role in forcing them to think about "the original meaning of the concept". Also, PB2 says that "education is very important, starting with higher education and then continuous education... they (accountants, N.A.) should expand their capacities to think, to judge, to estimate... In thinking the Romanian accountant is disadvantaged as compared to a European not to mention a British one. This is due to the fact that he believes that if he obeys the rules, he is the best accountant ever".

A1 thinks that "a problem is still the fact that users have not protested yet about TFV matters, as there has not been any law suit on TFV yet in Romania". Somehow, PB2 shares the same opinion: "the business environment should cry, the shareholders, as they are mostly affected". A1 believes that "it is a continuous learning process which needs both theory and practice", and it involves shareholders, administrators, auditors, and the regulator. The auditors (especially Big Four) and multinational companies are considered important in this change process by R1, citing the examples of the banking sector and of some big companies where "financial statements are more relevant".

Considering all these various assertions, we agree with $\mathrm{R} 1$ saying that "18 years are in fact not enough for TFV as things are moving slowly". However, we expect that this process of change will continue and the perception on TFV will evolve. 


\section{DISCUSSION AND CONCLUSION}

Romania has a code law system with an obvious preference for the legal form; all the interviewees tentatively agreed that this is the current situation in Romania. This way of thinking may even alter the implementation (use) of IASs, an auditor mentioning that these standards are applied in Romania in a "rule-based" not in a "principle-based" approach.

The translation of TFV (signifier) apparently does not influence the perception of different actors. The perception depends firstly on the category (auditor, preparer etc.), while other factors such as personal education ${ }^{13}$ also impact. For auditors, TFV is a guide or a vital concept, closely related to substance over form, relevance and usefulness for users. For regulators and preparers, TFV is primarily compliance with the rules. If a company has other users than the State, some more attention will be given to the image given by the financial statements (as regards the selection of accounting policies, the additional information disclosed). In this context, even if TFV override is allowed by the Romanian legislation, interviewed preparers have never used it because (mainly) of the fiscal controllers. Also, TFV is for regulators something exceptional; also, since the law encapsulates all the possible circumstances, it is somehow inconceivable to find this situation. Only an auditor for one of the Big Four indicated some examples of TFV override, where the auditor demanded some adjustments because he considered that the provisions of the law do not give a TFV.

It was a general idea (except for the regulator) that financial statements prepared according with the provisions of OMFP 1752 give a fiscal image, and that they are conceived for a single user - the State. Two sets of rules contribute to this situation: rules that impede the giving of a TFV (usually the preparers and auditors consider that the IASs treatment is more appropriate - such as for financial instruments, investment property, provisions), and rules which are applied in a fiscal manner (examples given by the interviewees were lease contracts, methods used for the assets' depreciation, adjustments for inventories or customers, revaluation of assets). The general assumption is that the financial statements prepared according to OMFP 1752 do not give a TFV. Some blame the regulators, others blame the accountants because they do not use their professional judgment, while a third group blamed was the users (and their lack of pressures). Accordingly, the users may be considered a first driver of the change in the perception of TFV in Romania, followed by the education, in order to form the abilities to make estimates or to use the professional judgment. Given the changes in the economical environment, it is expected that the perceptions (signified) will change.

Our study shows that Romania is another example of the transferability issue of constructs (in our case, TFV) in different cultures. The successive waves of reforms with French, British, $4^{\text {th }}$ Directive and IASs influences had, in our opinion, a small influence on the perception of TFV in Romania. The signifier was included in Romanian legislation in 1991 and did not change, while the code law accounting system marked TFV as being compliance with the rules (signified). However, the actors and their power (users and Big Four auditors) involved in the accounting process may influence (and in time, change) this perception. For the time being,

\footnotetext{
${ }^{13}$ Some of the interviewees mentioned an English-based education (ACCA etc.), while others were not even familiar with the English origin version of the concept (i.e. 'True and Fair View').
} 
the accountant is not perceived (not even by himself) as a driver of change regarding the image given by the financial statements.

Another question may be raised as to the TFV override issue. Only one interviewee was aware of such cases in Romania, while the others were neither aware nor trustful that such circumstances were to appear in the country's setting in the near future. While the signifier (TFV override) is the same, serious questions may be raised as to the transferability of its signified. We suspect that the cases where such a departure would appear in Romania would profoundly differ from the circumstances that would justify these cases in the UK, as the provisions of the law would probably not be as comprehensive as the ones in the UK. Also, the initiators of this act would probably differ in Romania from the ones in the UK: while in the UK, preparers are probably at least considering the TFV override as they apply their professional judgment, in Romania preparers do not seem at all interested/concerned/at ease in initiating such a procedure.

An interesting point may be raised regarding the hierarchy of legal texts in Romania. A recent paper concerns the prevalence of various legal texts in the context of two member states of the European Union (Alexander and Eberhartinger, 2009). The Romanian case may also be worth a short description, as it opposes both discussed cases (i.e. Austria and Germany), on a number of grounds. First, in Romania more than one type of legislation deals with accounting issues, as opposed to the two cases discussed (both of which include accounting issues in their respective Commercial Codes): the first is an organic law, i.e. the Accounting Law no. 82/1991 adopted by the Romanian Parliament, and revised as outlined in Section 2, while the second set is composed of Ministerial Orders as issued by the Romanian Ministry of Public Finance. These latter dealt through time with specific provisions for the harmonization/enactment of European Directives and/or IAS. The relationship between these sources is clearly established by the Law no. 24/2000 regarding the legislative technique for the establishment of legislative acts, revised in 2004 and modified by the Law no. 49/13/03/2007, when stating ${ }^{14}$ :

Art. 75

Normative orders, instructions and other similar acts issued by heads of ministries and other specialized bodies of central public administration or of bodies of autonomous administrative authorities are only issued on the foundation of, and in the application of, laws, Government decisions and ordinances.

Art. 76

The orders, instructions and other similar acts must be strictly limited to the framework constituted by the acts based on and in the application of which they have been issued, and cannot include solutions that would come in conflict with them.

\footnotetext{
14 Rough translation of art. 75 and 76 of the Law no. 24/2000 revised in 2004 and modified by the Law no. 49/13.03.2007: Art. 75 Ordinele cu caracter normativ, instrucțiunile şi alte asemenea acte ale conducătorilor ministerelor şi ai celorlalte organe ale administraţiei publice centrale de specialitate sau ale autorităţilor administrative autonome se emit numai pe baza şi în executarea legilor, a hotarârilor şi a ordonanțelor Guvernului; Art. 76 Ordinele, instrucțiunile şi alte asemenea acte trebuie să se limiteze strict la cadrul stabilit de actele pe baza şi în executarea cărora au fost emise şi nu pot conține soluții care să contravină prevederilor acestora.
} 
The second reason for difference is the case of TFV override, as in both cases addressed in Alexander and Eberhartinger (2009) the TFV override provision is not explicitly taken in the national legislation, with a stronger position in Germany. Interestingly, absolutely no reference is made in the Accounting Law no. 82/1991, not even in its revised version of 2008, to a TFV override. More, as already discussed in section 2 of the article, the TFV requirement does not seem superior to recognised compliance with applicable accounting regulations. Still, as the same section 2 presents, TFV override as indicated in the $4^{\text {th }}$ European Directive is taken in the OMFP 1752/2005 (it was introduced starting with the OMFP 403/1999 in the Romanian legislation as shown previously). In summary, the override is explicit in the Ministry regulation, but not in the law, which is superior to the regulations. However, the law is silent on the matter, and Alexander and Eberhartinger (2009) provide evidence that in such circumstances the European Court of Justice would confirm the supremacy of the Fourth Directive requirement over the national wordings (presumably only since 1 January 2007 when Romania joined the European Union). Reading this in the context of art. 76 of the Law $24 / 2000$, one may wonder as regards a possible inconsistency between the provisions of the two accounting acts. The Lex specialis derogat lex generalis principle specific to Roman law systems cannot be invoked here, as it would presume that the two acts have equal authority, which they have not. Our Romanian colleague specialized in commercial law also raised several issues upon seeing the present form (as of March 1, 2009) of the provisions of the two accounting acts (Accounting Law in its 2008 revision and the OMFP 1752). The far most important one deals with the TFV override, as she claimed that this provision should have been included in the Accounting Law (especially in its 2008 revision) and also remain incorporated in the OMFP 1752; she also commented that this provision should be included in a future revision of the Accounting Law (even of strictly from a legal point of view this does not have immediate consequence), even if she specifically asserted that there is no actual conflict between the provisions of the two acts, as "the provisions of the $4^{\text {th }}$ ED annul the provision of a national act which would be in conflict with the former". In other words the provision regarding the TFV override being not included in the Law no.82/1991 as revised in 2008 while being included in the OMFP 1752 is theoretically speaking wrong, considering that the OMFP 1752 is the juridical form chosen by Romania to transpose the ED into the Romanian legal system, and the other modifications of the Accounting Law no.82/1991 adopted in 2008 are not contrary to the provisions of ED and especially to its result (that has to be achieved). It also results that the OMFP 1752 is consistent with the legal principles regarding the legal force of normative acts (in Romania) and the priority of EU law.

A second concern dealt with the term 'trebuie' (en. must; fr. il faut que) missing in the phrasing of the OMFP 1752. As previously discussed in this paper (section 3), this lack may give rise to misinterpretations; there is some support in the discussions we had with our Romanian law colleague that the term needs to be included in the phrasing of the Order, as it is also present in the phrasing of the $4^{\text {th }}$ ED (in its English and French versions) and the local Accounting Law.

Given this complexity, however, there is no wonder in this context that Romanian accountants do not seem enthusiastic about departing from an accounting provision in order to give a TFV! Auditors (especially one of Big Four) are more likely to demand such a departure as they would feel necessary in order to give a TFV by Romanian companies. Also, the 
Romanian accountancy profession may be unprepared for a genuine application of these concepts. The tradition of rules based accounting may very well cause this approach. All this discussion may raise serious questions as to the success of the full transfer of the TFV concept to Romania.

The detailed material explored in this paper raises issues of general importance and interest in several respects. Romania is an example of a so-called transitional economy, i.e. an excommunist East-European satellite country, advancing firmly towards Western capitalism, but very clearly in the second wave, rather than the first. It is a rational hypothesis, testable by other researchers, that similar attitudinal issues and difficulties are likely to arise in other similar countries.

Secondly, it is a transitional economy more influenced than many by a legalistic code-law tradition common in many European (and perhaps South American) countries. An assumption of a more-or-less automatic supremacy of detailed regulations and an expectation of detailed instructions (found also, for example, in the Chinese standards "adopting" IFRS) is a wide-spread phenomenon. Again, there are likely, and researchable, implications for the adoption of an IFRS way of thinking (whether or not linked also with EU Directives). Could this, for example, be directly consistent with a French antithesis to many of the IFRS developments of the last few years?

There are two more general issues of rules-based thinking. Could there be messages here regarding US attitudes to the realities of accepting the relative flexibility of IFRS? It was explicitly suggested by an auditor interviewee (as a matter for criticism) that Romania tended to adopt a US- style rules focus on the preparation of financial statements.

Finally, although our sample has no purely statistical validity, it is interesting to note the clear dichotomy between two groups of the leading players interviewed. Auditors and preparers tend to regard the rules of OMFP as failing to give a TFV in the user-focussed sense in which they perceive it. Indeed there are suggestions that it is explicitly designed NOT to give a TFV, but to satisfy state and fiscal needs instead, despite its ostensible explicit statement of an over-ride. Regulators, with some support from Professional Body representatives, see no such contradiction. This dichotomy should be investigated elsewhere. The suggestion that "we do not have standards, we have [state] regulations", also resonates with the determination of the IASB to preserve its private sector independence against the interfering statism of parts of the EU (the French in particular, perhaps).

Our in depth analysis is seen to present potentially generalisable important issues, worthy of extension and developed elsewhere.

\section{Acknowledgments}

The authors wish to thank the two anonymous reviewers of the AFC congress in Strasbourg for their useful suggestions and comments. Also, we wish to warmly thank Prof. Cornelia Lefter of the Bucharest Academy of Economic Studies for her in-depth suggestions and advice regarding the legal matters in Romania. 


\section{REFERENCES}

Alexander D. (1993) “A European True and Fair View?”, European Accounting Review, 2(1), pp. 59-80

Alexander D. (1999) "A benchmark for the adequacy of published financial statements", Accounting and Business Research, 29(3), pp. 239-253

Alexander D. (2001) “The over-riding importance of internationalism: a reply to Nobes”, Accounting and Business Research, 31(2), pp. 145-149

Alexander D., Jermakowicz E. (2006) "A true and fair view of the principles/rules debate", Abacus, 42(2), pp. $132-164$

Alexander D. and Eberhartinger E. (2009) "The true and fair view in the European Union", European Accounting Review (forthcoming)

Benston J., Bromwich M. and Wagenhofer A. (2006) "Principles versus rules-based accounting standards: the FASB's standard-setting strategy", Abacus, 42(2), pp. 165-188

Bunea S. (2006) “Analiza impactului procesului de convergență asupra evoluției unor sisteme contabile naţionale şi învăţăminte pentru România" [Analysis of the impact of the convergence process on the evolution of national accounting systems and lessons for Romania], The XVIth Congress of Romanian accounting profession, Bucharest, 15-16 Sept.

Burlaud A. (1993) “Commentary on the article by David Alexander 'A European true and fair view”, European Accounting Review, 2(1), pp. 95-98

Calu D.A. (2005) Istorie şi dezvoltare privind contabilitatea din România [History and development regarding Romanian accounting], published $\mathrm{PhD}$ thesis, Bucureşti: Economică

Chastney J. (1975) "True and fair view - history, meaning and the impact of the Fourth Directive", Institute of Chartered Accountants in England and Wales: London

Delesalle F.E. and Delesalle E. (2000) La comptabilité et les dix commandements, Paris : Fid Edition

Evans L. (2003) “The true and fair view and the 'fair presentation' override in IAS 1", Accounting and Business Research, 33(4), pp. 311-325

Feleagă N. (1992) Problèmes du choix et de l'implantation d'un nouveau système comptable dans un pays qui passe d'une économie planifiée et centralisée à l'économie de marché - le cas de la Roumanie, Actes du 13 e congrès de l'AFC, Bordeaux, 21-23 mai

Feleagă, N. and Ionaşcu, I. (1998) Tratat de contabilitate financiară, vol. I [Treatise of financial accounting, vol. 1], Bucureşti: Economică

IASC (1989) "Framework", IASC, London

Ionaşcu I, Ionaşcu M., Olimid L. and Calu D.A. (2007) “An empirical evaluation of the costs of harmonizing Romanian accounting with International Regulations (EU Directives and IAS/IFRS)", Accounting in Europe, 4(1-2), pp. 169-206

Kirk N. (2006) "Perceptions of the true and fair view concept: An empirical investigation", Abacus, 42(2), pp. 205-235

Kosmala K. (2005) "True and fair view or rzetelny i jasny obraz? A survey of Polish Practitioners", European Accounting Review, 14(3), pp. 579-602

Nobes C. (1983) “A judgemental international classification of financial reporting practices", Journal of Business Finance and Accounting, Spring

Nobes, C. (1993) "The true and fair view requirement: impact on and of the Fourth Directive", Accounting and Business Research, 24(3), pp.35-48

Nobes, C. (1998) "Towards a general model of the reasons for international differences in financial reporting", Abacus 34(2)

Nobes, C. (2000) "Is true and fair of overriding importance? A comment on Alexander's benchmark", Accounting and Business Research, 3(4), pp. 307-312

Paler O. (1995) Vremea întrebărilor [A time to question], Ed. Albatros, Ed. Universal Dalsi 
Roberts A. (2000) The recent Romanian accounting reforms: another case of cultural intrusion?, in Kalyuzhnova, Y. and Taylor, M. (Eds.) Transitional Economies: Banking, Finance, Institutions, pp. 146 - 166 (Basingstoke: Palgrave)

Schroll R. (1995) “The new accounting system in the Czech Republic", European Accounting Review, 4:4, 827832

Sucher P., Seal W. and Zelenka I. (1996) "True and fair view in the Czech Republic: a note on local perceptions", European Accounting Review, 5(3), pp. 545-557

Walton, P. (1991) "The true and fair view: a shifting concept", ACCA Occasional Paper No. 7, Chartered Association of Certified Accountants, London

*** A patra directivă a consiliului Comunităților Europene din 25 iulie 1978, privind conturile anuale ale anumitor forme de societăți comerciale (78/660/CEE), versiune consolidată 1 ianuarie 2007 (odată cu aderarea României şi Bulgariei la Uniunea Europeană), publicată în Jurnalul Oficial al Uniunii Europene, L 222, 14.8.1978, p. 11 [Fourth Council Directive of 25 July 1978, on the annual accounts of certain types of companies (78/660/CEE), as published on January 1, 2007 as a result of Romania and Bulgaria adhering to the European Union, European Union Official Journal, L 222, 14.8.1978, p. 11]

*** Legea contabilității nr. 82/1991, Monitorul Oficial nr. 265/27.12.1991, republicată în Monitorul oficial al României nr. 454/18.06.2008 [Accounting Law no. 82/1991, Official Journal of Romania no. 265/27.12.1991, revised, Official Journal no. 454/18.06.2008]

*** Lege privind normele de tehnică legislativă pentru elaborarea actelor normative nr. 24/2000, republicată în 2004, Monitorul Oficial al României, Partea I, nr. 777 din 25 august 2004, şi modificată şi completată prin legea nr. 49/13.03.2007 [Law no. 24/2000 regarding the legislative technique for the establishment of legislative acts, revised in 2004, Official Journal of Romania, Part I, no. 777/25.08.2004, and modified by the Law no. 49/13.03.2007]

*** Hotărârea guvernului nr. 704/1993 pentru aplicarea legii contabilității, Monitorul Oficial al României nr. 303bis/22.12.1993 [Government decision no. 704/1993 for the implementation of the Accounting Law no. 82/1991, Official Journal of Romania no. 303bis/22.12.1993]

*** Ordinul Ministrului Finanțelor nr. 403/1999 privind aprobarea reglementărilor contabile armonizate cu Directiva a IV-a a Comunităţilor Economice Europene (CEE) si cu Standardele de Contabilitate Internaționale, Monitorul Oficial al României, nr. 480/4.10.1999 [Order of the Minister of Finances no. $403 / 1999$ for the approval of the accounting regulations harmonized with the $4^{\text {th }}$ European Directive and International Accounting Standards, Official Journal of Romania, no. 480/4.10.1999]

*** Ordinul Ministrului Finanțelor Publice nr. 94/2001 pentru aprobarea Reglementărilor contabile armonizate cu Directiva a IV-a a CEE şi cu Standardele de Contabilitate Internaționale, Monitorul Oficial al României nr. 85/20.02.2001 [Order of the Minister of Public Finances no. 94/2001 for the approval of the accounting regulations harmonized with the $4^{\text {th }}$ European Directive and International Accounting Standards, Official Journal of Romania, no. 85/20.02.2001]

*** Ordinul Ministrului Finanțelor Publice nr. 306/2002 pentru aprobarea Reglementărilor contabile simplificate, armonizate cu directivele europene, Monitorul Oficial al României, nr. 279/25.04.2002 [Order of the Minister of Public Finances no. 306/2002 for the approval of the simplified accounting regulations harmonized with the European Directives, Official Journal of Romania, no. 279/25.04.2002]

*** Ordinul Ministrului Finanțelor Publice (OMFP) nr. 1775/2004 privind unele reglementări în domeniul contabilității, Monitorul Oficial al României nr. 27 bis/10.01.2005 [Order of the Minister of Public Finances no. 1775/2004 regarding some regulations in accounting, Official Journal of Romania no. 27 bis/10.01.2005]

*** Ordinul Ministrului Finanțelor Publice (OMFP) nr. 1752/2005 pentru aprobarea Reglementărilor contabile conforme cu Directivele Europene, Monitorul Oficial al României nr. 1080 bis/30.11.2005 [Order of the Minister of Public Finances no. 1752/2005 for the approval of accounting regulations in accordance with the European Directives, Official Journal of Romania, no. 1080 bis/30.11.2005]

*** Ordinul Ministrului Finanțelor Publice (OMFP) nr. 1121/2006 privind aplicarea Standardelor Internaționale de Raportare Financiară, Monitorul Oficial al României, nr. 602/12.07.2006 [Order of the Minister of Public Finances no. 1121/2006 for the application of the International Financial Reporting Standards, Official Journal of Romania, no. 602/12.07.2006] 
Appendix A - List of interviewees

\begin{tabular}{|l|l|c|l|l|}
\hline & Category & Abbreviation & Duration & Date \\
\hline 1. & Preparer & P1 & 50 min. & November 28, 2008 \\
\hline 2. & Preparer & P2 & 70 min. & December 1, 2008 \\
\hline 3. & Preparer & P3 & 45 min. & December 12, 2008 \\
\hline 4. & Auditor & A2 & 60 min. & December 3, 2008 \\
\hline 5. & Auditor & R1 & 60 min. & December 16, 2008 \\
\hline 6. & Regulator & R2 & 45 min. & December 10, 2008 \\
\hline 7. & Regulator & PB1 & 75 min. & November 26, 2008 \\
\hline 8. & $\begin{array}{l}\text { Representative of the Chamber of } \\
\text { Financial Auditors of Romania } \\
\text { [Camera Auditorilor din România] }\end{array}$ & PB2 & 50 min. & December 22, 2008 \\
\hline 9. & $\begin{array}{l}\text { Representative of the Body of } \\
\text { Expert and Licensed Accountants } \\
\text { of Romania [Corpul Experților } \\
\text { Contabili şi Contabililor Autorizați } \\
\text { din România] }\end{array}$ & & & \\
\hline
\end{tabular}

